\title{
Dinosaur footprints in the Early Jurassic of Patagonia (Marifil Volcanic Complex, Argentina): biochronological and palaeobiogeographical inferences
}

\author{
IGNACIO DÍAZ-MARTÍNEZ*†,SANTIAGO N. GONZÁLEZ* \& SILVINA DE \\ VALA I S * \\ * CONICET - Instituto de Investigación en Paleobiología y Geología, Universidad Nacional de Río Negro, Av. Roca \\ 1242, General Roca (8332), Río Negro, Argentina
}

(Received 10 August 2016; accepted 3 February 2017)

\begin{abstract}
A new dinosaurian track-bearing site, with tridactyl footprints from the Lower Jurassic (pre-middle Pliensbachian) volcanogenic and epiclastic rocks of the Marifil Volcanic Complex, Patagonia, Argentina, is presented and described. The best-preserved footprint, classified as cf. Anomoepus, confirms the utility of the Anomoepus-like tracks for the Early Jurassic biochronology. Palaeobiogeographically, this record supports the idea that the South American Early Jurassic dinosaur fauna presents elements of Pangaean distribution, and others with Gondwanan relationships with prevalent southern African affinities. Dinosaur records from South America between the Rhaetian and the Pliensbachian are very scarce, and this find contributes to the knowledge of early radiation and evolution of Dinosauria.
\end{abstract}

Keywords: Anomoepus-like tracks, pre-middle Pliensbachian, ichnology, South America, volcanogenic rock

\section{Introduction}

Dinosaurs originated, radiated and became the dominant vertebrate group in continental tetrapod communities of the world during most of the Mesozoic (Benton, 1983; Brusatte et al. 2008, 2010). An important part of their history is preserved in the sedimentary successions cropping out in Patagonia, Argentina (e.g. Casamiquela, 1964; Bonaparte \& Vince, 1979; Salgado \& Bonaparte, 1991; Coria \& Salgado, 1995; Novas, 2009), ranging from the early stages after their origin in the Late Triassic up to their extinction in the uppermost Cretaceous rocks (see Novas, 2009, and references therein). Nevertheless, the history is far from being completely known and any new data will be crucial to understand both the early radiation of Dinosauria in Patagonia and the first steps of the Mesozoic tetrapod fauna that evolved in Gondwana.

During the 1950s, a new dinosaurian track-bearing layer was found in a flagstone quarry in the Lower Jurassic age (pre-middle Pliensbachian; see below) Marifil Volcanic Complex (MVC), in the SE of Río Negro province, Patagonia, Argentina. To date, there have been no discoveries of

$\dagger$ Author for correspondence: inaportu@hotmail.es vertebrate remains in the MVC. For the large temporal interval of c. $26 \mathrm{Ma}$ from the Rhaetian (uppermost Triassic) to the Pliensbachian (middle Early Jurassic), dinosaur remains have been very scarce in South America (Barrett et al. 2008, 2014; Martínez, 2009; Apaldetti et al. 2011; Pol, Garrido \& Cerda, 2011; Langer et al. 2014). This contrasts with the abundant information available from younger and older levels (e.g. Bonaparte, 1971; Báez \& Marsicano, 2001; Arcucci, Marsicano \& Caselli, 2004; Salgado \& Gasparini, 2004; Langer, 2005; Rauhut et al. 2005; Pol \& Powell, 2007; de Valais, 2011; Pol, Rauhut \& Becerra, 2011; Pol \& Rauhut, 2012).

This study aims to present, describe and analyse the new ichnological material found in the MVC. In addition, the biochronological and palaeobiogeographical significance of these dinosaur footprints is discussed in the context of the geological evolution and global tetrapod faunal composition of Patagonia and also Gondwana.

\section{Geological setting}

The MVC represents a large magmatic Mesozoic event in the eastern North Patagonian Massif, Argentina (Pankhurst et al. 1998, and references therein). It comprises a large volume of acidic (rhyodacites to rhyolites) ignimbrites with minor rhyolitic and andesitic lava flows, and sedimentary lenses interbedded within the acidic volcanic succession (Cortés, 1981). A variety of igneous rocks from the MVC have been dated by several radiometric methods $(\mathrm{Rb}-\mathrm{Sr}, \mathrm{K}-\mathrm{Ar}, \mathrm{Ar}-\mathrm{Ar}$ and $\mathrm{U}-\mathrm{Pb}$ ), ranging from 221 to $165 \mathrm{Ma}$ (Cortés, 1981; Pankhurst et al. 1998, 2000; Féraud et al. 1999, and references therein). Because of its overall rhyolitic composition and the proposed Jurassic age, the MVC has been included in the Chon Aike Large Silicic Igneous Province (Pankhurst et al. 2000).

In the study area, rhyolitic ignimbrites of $188 \mathrm{Ma}(\mathrm{Rb}-\mathrm{Sr}$ age, in Pankhurst \& Rapela, 1995) overlay a series of acidic to mesosilicic igneous and pyroclastic rocks and thin epiclastic lenses. The ichnosite is located $50 \mathrm{~km} \mathrm{SW}$ of Sierra Grande, Río Negro province, in a farm owned by the Perdomo family (Fig. 1). The $30 \mathrm{~m}$ succession containing the flagstone quarry, which had fielded the track-bearing slabs, is dominated by pyroclastic acidic flows with a thin volcanogenic epiclastic lens (Fig. 2). The track-bearing slabs are composed of coarse-grained light-pinkish sandstone with 


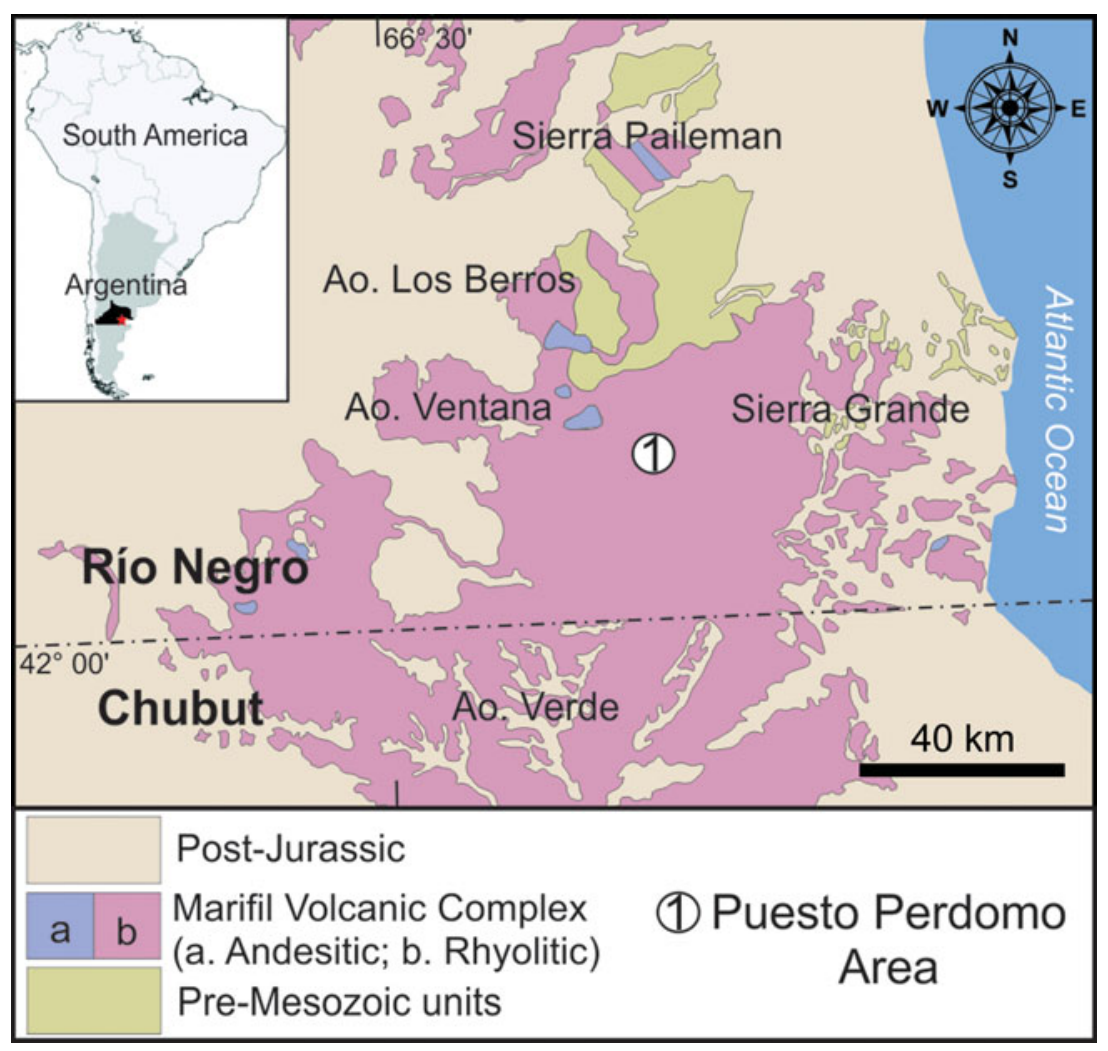

Figure 1. (Colour online) Local geological map with the location of Sierra Grande - Arroyo de la Ventana area and the new dinosaurian track-bearing site.

quartz, k-feldspar and pyroclastic material (ash and pumice fragments), which come from the base of the $1 \mathrm{~m}$ thick epiclastic lens in the analysed succession (Fig. 2). The coarse sandstones are interbedded with fine-grained brownish sandstone on which the dinosaur probably stepped, given that the tracks studied here are the infill of the original footprints. At the top of epiclastic lenses, plant remains attributable to equisetals (M. G. Passalia \& A. Iglesias, pers. comm., 2015) were found. Flat lamination and ripple marks are also present at the epiclastic levels.

The described epiclastic rocks and dinosaur tracks are time-constrained by the andesitic rocks at the base of the MVC (221 Ma, Carnian, Late Triassic) and the upper acidic rhyolitic ignimbrites at the top (188 Ma, early Pliensbachian, Early Jurassic). Because of their acidic pyroclastic component precedent from the overlaying rhyolitic complex, the epiclastic lenses are assigned to the Early Jurassic gap of the Marifil Volcanism (pre-middle Pliensbachian) (Cortés, 1981; Pankhurst \& Rapela, 1995).

The thickness of the epiclastic succession and the observed palaeontological and sedimentological features suggest that the sedimentation occurred in a small fluvial system, where the sandstones correspond with the erosion of the ignimbrites infilling small palaeochannels by mediumenergy currents. The volcanism of the MVC may have controlled the sedimentation and the development of the fluvial system.

\section{Material and methods}

The tracks were collected in situ by the Perdomo family in the 1950s, from a flagstone quarry; in the 2000s, the material was donated to the Museo Regional Provincial de Valcheta, Valcheta town, Río Negro province, and housed under the acronym MRPV. The specimens are six trace fossils preserved as positive relief, in four sandstone slabs (Fig. 3). Their collection numbers are MRPV 427/P/13, 428/P/13, 429/P/13, 430/P/13.1, 430/P/13.2 and 430/P/13.3 (the last three specimens are in the same slab).

The ichnotaxonomic approaches to tridactyl footprints of Gierliński (1991), Olsen \& Rainforth (2003) and Li et al. (2012) have been followed. Measurements and nomenclature are mainly based on the criteria of Leonardi (1987) and Haubold (1971). The measurements (Table 1) were: footprint length (FL), footprint width (FW), digit impression length (II, III and IV) and digit impression divarication angles (II-III, III-IV, II-IV). A further parameter is the ratio between the maximum height and the perpendicular transverse base of the anterior triangle (AT) formed by digit II, III and IV tip imprints (sensu Lockley, 2009, and references therein).

Photogrammetric models (Mallison \& Wings, 2014) (Fig. 3) were obtained using Agisoft PhotoScan ${ }^{\text {TM }}$ (version 0.8.5.1423) software (Grupo Aragosaurus, Universidad de Zaragoza License), and imported into Meshlab (version v1.3.3) and Paraview (version 3.14.1) software packages in which depth and contour line analysis was produced.

\section{Results}

The four pedal impressions are tridactyl, subsymmetric and mesaxonic. They are longer than wide and present the 'heel' impression almost directly or directly aligned with the axis of digit III impression.

MRPV 427/P/13 (Fig. 3a) is a natural cast, $131.3 \mathrm{~mm}$ long and $100.3 \mathrm{~mm}$ wide (length/width ratio: 1.31 ). The digit impressions are slender, longer than wide and are 55.5, 81 and $61 \mathrm{~mm}$ long for digits II, III and IV imprints, respectively. Claw and pad impressions are not evident. The divarication angles are II-III $31^{\circ}$, III-IV $51^{\circ}$ and II-IV $68^{\circ}$. The AT is 0.51 . 


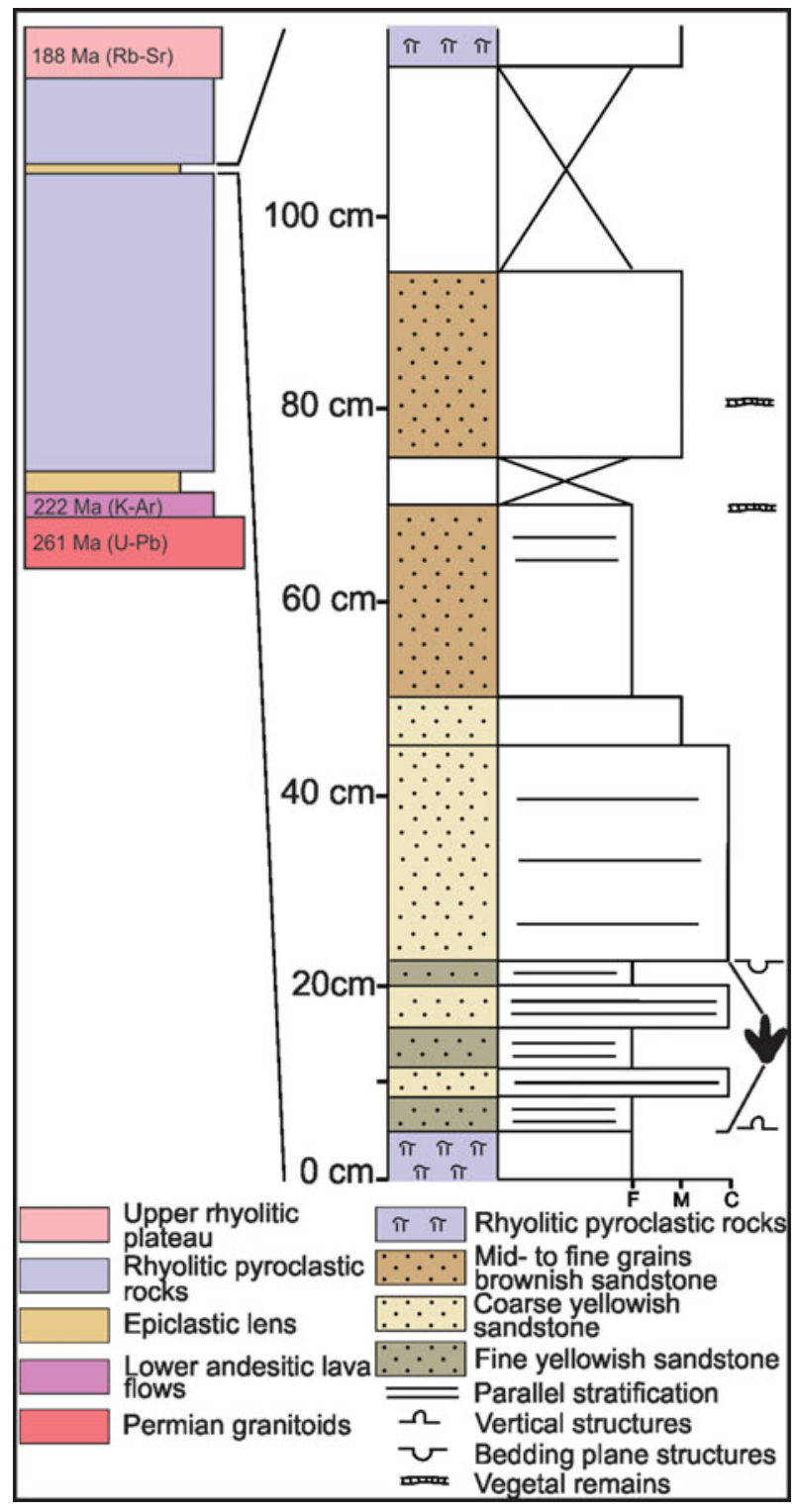

Figure 2. (Colour online) General, simplified, stratigraphic section of MVC and detailed stratigraphic section of Perdomo's quarry. Ages are based on references in the text.

MRPV 428/P/13 is a very irregular and poorly preserved natural cast, with a centimetric layer (undertrack cast) covering the footprint (Fig. 3b). The digit impressions are broad, wider than long. The track is about $172 \mathrm{~cm}$ long and $135 \mathrm{~cm}$ wide but we consider these measurements unrepresentative due to poorly-preservation.

MRPV 429/P/13 (Fig. 3c) is a natural cast that is $175 \mathrm{~mm}$ long and $127 \mathrm{~mm}$ wide (length/width ratio: 1.37 ). The digit impressions are slender and longer than wide. The digit III impression is $111 \mathrm{~mm}$ long. The other digit impressions are too poorly preserved to provide reliable measurements. The divarication angle II-IV is $52^{\circ}$. The AT is 0.53 .

The three impressions of MRPV430/P/13 are preserved as natural casts. MRPV 430/P/13.1 (Fig. 3d-f) is the best preserved. It is a footprint $187 \mathrm{~mm}$ long and $128.3 \mathrm{~mm}$ wide (length/width ratio: 1.46). The digit impressions are slender, longer than wide and show clear digital pad imprints. The digit II impression is shifted anteriorly with respect to digits III and IV, displaying a characteristic posteromedial notch, indicating this is a right pes. The relative digit lengths are III $>$ IV > II (106, 81 and $71 \mathrm{~mm})$. The metatarsophalangeal pad trace is very clear, as well as the claw traces of digit II and III impressions, laterally and anteriorly directed respectively. The impression of digit IV projects slightly further than the digit II impression. The divarication angle II-IV is $58^{\circ}$ (II-III is $19^{\circ}$, III-IV is $27^{\circ}$ ). The AT is 0.50 . On the same slab, there are two ovoid traces positioned close to the tridactyl track MRPV 340/P/13.1 (Fig. 3d-f). One (430/P/13.2), of about $80 \mathrm{~mm}$ diameter, is located $100 \mathrm{~mm}$ on the left of the 'heel' impression, and the other $(430 / \mathrm{P} / 13.3)$, of about $50 \mathrm{~mm}$ diameter, is $70 \mathrm{~mm}$ in front of the anterior part of the digit III impression.

\section{Discussion and conclusions}

\section{5.a. Ichnotaxonomy}

The studied footprints display different kinds of preservation. With this in mind, the general and recurrent tridactyl shape shows that the tracks are all very alike and variation in the morphology may represent the product of taphonomical variability. Because of the observed preservational variants due to taphonomy, tracks were classified in different ichnotaxonomical levels, from the best-preserved track MPV 430/P/13.1, assigned to a higher ichnotaxonomical status, to the other three tracks. In fact, the poorly preserved MVP $427 / \mathrm{P} / 13,428 / \mathrm{P} / 13$ and $429 / \mathrm{P} / 13$ do not display sufficiently clear morphological details to undertake an ichnotaxonomical assignment with confidence.

The principal features shared by the footprints (i.e. tridactyl, roughly symmetrical, mesaxonic, longer than wide, 'heel' impression in line with the axis of digit III impression) are common in some theropod and ornithischian ichnotaxa, such as Anomoepus Hitchcock, 1848, Ornithomimipus Sternberg, 1926, Saurexallopus Harris, 1997 or Dinehichnus Lockley et al. 1998, among others (Wright, 2004). MVP 428/P/13 presents broader digit impressions than the other three tracks, likely due to the natural-cast flattening phenomenon (Lockley \& Xing, 2015). In the case of MVP $427 / \mathrm{P} / 13,428 / \mathrm{P} / 13$ and 429/P/13, their general features are approximately their whole description and they have no other peculiarities to relate them to a particular ichnotaxon. Therefore, we classify these footprints as indeterminate dinosaur footprints.

MPV 430/P/13.1 is the best-preserved specimen from the Perdomo site. It mainly differs from the typical Late Triassic-Early Jurassic theropod ichnotaxa Eubrontes Hitchcock, 1845, Anchisauripus Lull, 1904 and Grallator Hitchcock, 1858 because the former is roughly symmetrical and presents a metatarsophalangeal pad impression in line with the axis of the digit III impression, while the latter are asymmetrical with the metatarsophalangeal pad impression laterally located.

MPV 430/P/13.1 displays similar ichnotaxobases to some ichnogenera that belong to the ornithischian ichnofamily Anomoepodidae Lull, 1904 (i.e. symmetry, position and the shape of the metatarsophalangeal pad impression and digital pad impressions; Fig. 3d-f), such as Anomoepus, Moyenisauropus Ellenberger, 1970, and Shenmuichnus Li et al. 2012 (Anomoepus-like ichnotaxa in this work). These ichnogenera share several features (bipedal or quadrupedal trackways, pentadactyl hand prints and tridactyl or tetradactyl footprints), causing their ichnotaxonomy to be disputed. For instance, some authors have considered Moyenisauropus as a junior synonym of Anomoepus (Olsen \& Galton, 1984; Olsen \& Rainforth, 2003), while others argue that they are different ichnogenera (Gierliński, 1999; Lockley \& Gierliński, 2006; Dalman \& Weems, 2013). Li et al. (2012) suggest that Shenmuichnus has a lower heteropody 

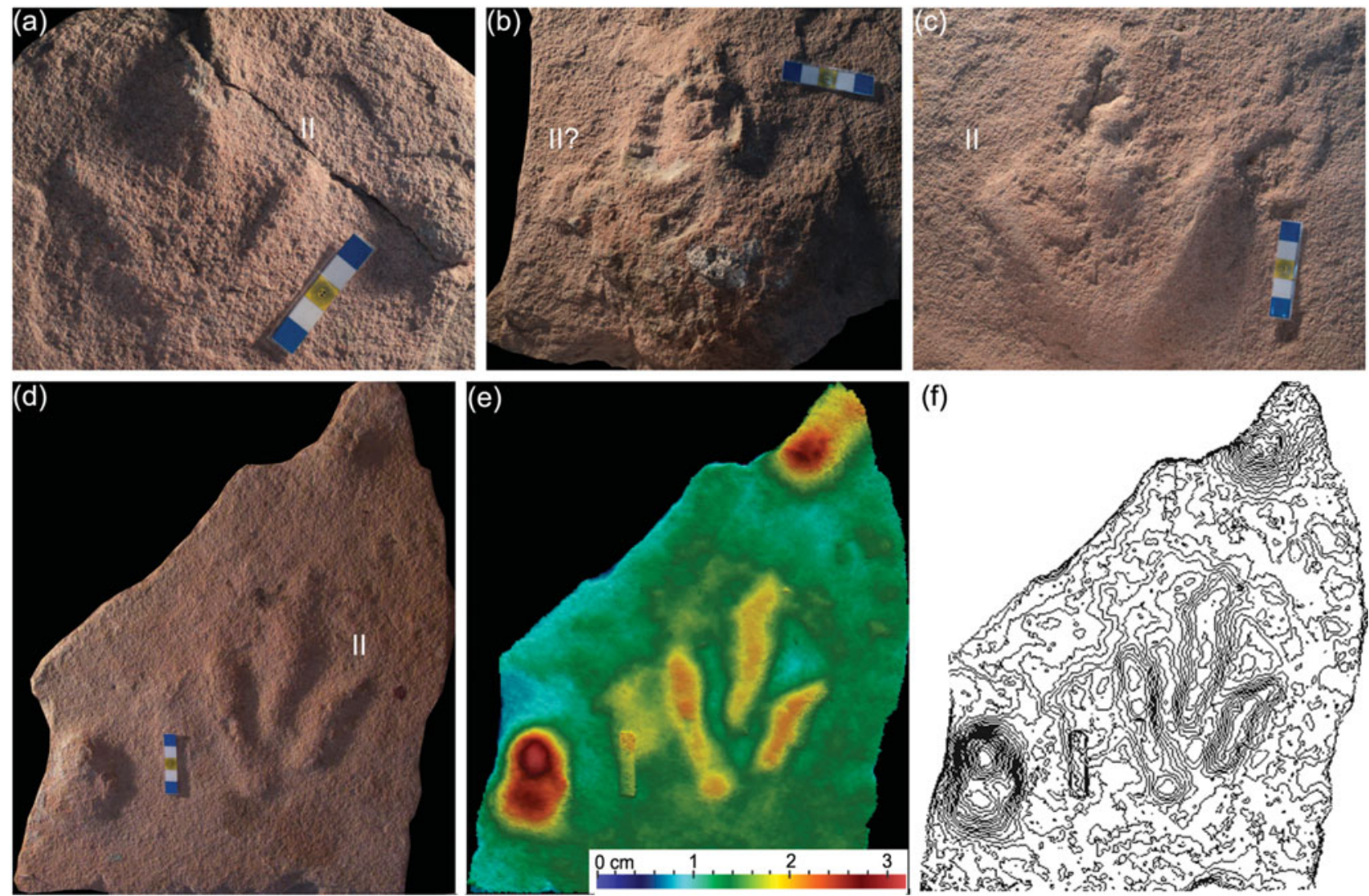

Figure 3. (Colour online) MVC dinosaur footprints. (a) MRPV 427/P/13; (b) MRPV 428/P/13; (c) MRPV 429/P/13; (d) MRPV 430/P/13; (e) false-coloured 3D depth analysis model of MRPV 430/P/13; and (f) contour line map with 1 mm of equidistance of MRPV 430/P/13. Scale bar: $5 \mathrm{~cm}$. II: digit II impression.

from Moyenisauropus and Anomoepus and the lack of claw impressions. Gierliński (1991) described Moyenisauropus more robust than Anomoepus (as in Shenmuichnus; sensu Xing et al. 2016b) and with subequally lengthened digit impressions on the manus tracks. The MPV 430/P/13.1 footprint is gracile and preserves claw impressions, so we propose a relationship with Anomoepus. As noted above, the manus impression is important in the ichnotaxonomy of Anomoepus-like ichnotaxa. Close to MPV 430/P/13.1, there are two traces (MPV 430/P/13.2-3; Fig. 3d-f) that might be considered as manus impressions. Nevertheless, these impressions could also be interpreted as part of an undetermined, partial and poorly preserved distinctive trackway. Lockley \& Gierliński (2006) suggested that Anomoepus is hard to identify with confidence unless both manus and pes impressions were found. Therefore, we classified MPV430/P/13.1 as cf. Anomoepus due to its similarity to this ichnotaxon but lack of a clear manus impression.

\section{5.b. Trackmaker affinity and South American coetaneous dinosaur diversity}

The Anomoepus-like tracks have been related to ornithischian trackmakers by several authors (e.g. Lull, 1904; Haubold, 1971; Olsen \& Galton, 1984; Gierliński, 1991; Olsen \& Rainforth, 2003). A criterion has been the presence of the dinosaurian pes and the pentadactyl manus impressions (Olsen \& Rainforth, 2003). These authors suggest that the manus track lacks enlarged digit I, II and III impressions, which is related to the manual phalangeal formula of Ornithischia. Within this clade, basal members of ornithischians, ornithopods or thyreophorans have been cited as possible trackmakers (e.g. Thulborn, 1990; Gierliński, 1999; Olsen \& Rainforth, 2003; Li et al. 2012). Therefore, Olsen and Rainforth (2003) suggested that the producer of Anomoepus was a relatively small, gracile, facultatively bipedal ornithischian.

As stated above, dinosaur remains are very scarce in the Rhaetian-Pliensbachian of South America (Barrett et al. 2008, 2014; Martínez, 2009; Apaldetti et al. 2011; Pol, Garrido \& Cerda, 2011; Langer et al. 2014) and the studied tracks represent the first ichnological record from this time interval in the region. Moreover, if we are correct in our appraisal that the trackmaker of MPV 430/P/13.1 was an ornithischian, then the studied tracks would also represent the second evidence of the occurrence of this clade in South America during the same time interval (the first is $L a$ quintasaura venezuelae Barrett et al. 2014, lowermost Hettangian La Quinta Formation, Venezuela). This find could confirm the presence of ornithischians in Patagonia between the Norian cf. Heterodontosaurus sp. from the Laguna Colorada Formation (Báez \& Marsicano, 2001), and the Toarcian Manidens condoriensis Pol, Rauhut \& Becerra, 2011 and Heterodontosauridae indet. (Becerra et al. 2016) from the Cañadón Asfalto Formation.

Prior to this study, only one Patagonian dinosaur had ever been documented from the Rhaetian-Pliensbachian lapse: the basal sauropodomoph Leonerasaurus Pol, Garrido \& Cerda, 2011, from the Sinemurian-Pliensbachian Las Leoneras Formation (Cañadón Asfalto basin, Chubut province; age sensu Cúneo et al. 2013). The scarcity of vertebrate fossils from the Rhaetian-Pliensbachian time interval strongly contrasts with the abundant known fossilbearing horizons from older (e.g. Casamiquela, 1964; Báez \& Marsicano, 2001; Pol \& Powell, 2007) and younger (e.g. 
Table 1. Measurements of MVC dinosaur footprints

\begin{tabular}{|c|c|c|c|c|c|c|c|c|c|}
\hline & $\begin{array}{c}\mathrm{FL} \\
(\mathrm{mm})\end{array}$ & $\begin{array}{c}\mathrm{FW} \\
(\mathrm{mm})\end{array}$ & $\begin{array}{c}\mathrm{II} \\
(\mathrm{mm})\end{array}$ & $\begin{array}{c}\text { III } \\
(\mathrm{mm})\end{array}$ & $\begin{array}{c}\mathrm{IV} \\
(\mathrm{mm})\end{array}$ & $\begin{array}{c}\text { II-III } \\
\left(^{\circ}\right)\end{array}$ & $\begin{array}{c}\text { III-IV } \\
\left({ }^{\circ}\right)\end{array}$ & $\begin{array}{c}\text { II-IV } \\
\left(^{\circ}\right)\end{array}$ & AT \\
\hline MRPV 427/P/13 & 131 & 100 & 55.5 & 81 & 61 & 31 & 51 & 68 & 0.51 \\
\hline MRPV 428/P/13 & $172 ?$ & $135 ?$ & & & & & & & \\
\hline MRPV 429/P/13 & 175 & 127 & & 111 & & & & 52 & 0.53 \\
\hline MRPV 430/P/13.1 & 187 & 128 & 71 & 106 & 81 & 19 & 27 & 58 & 0.50 \\
\hline
\end{tabular}

Abbreviations: FL, footprint length; FW, footprint width; II: digit II length; III: digit III length; IV: digit IV length; II-III: angle between digits II and III; III-IV: angle between digits III and IV; II-IV: angle between digits II and IV; AT: anterior triangle. AT is an index and therefore dimensionless.

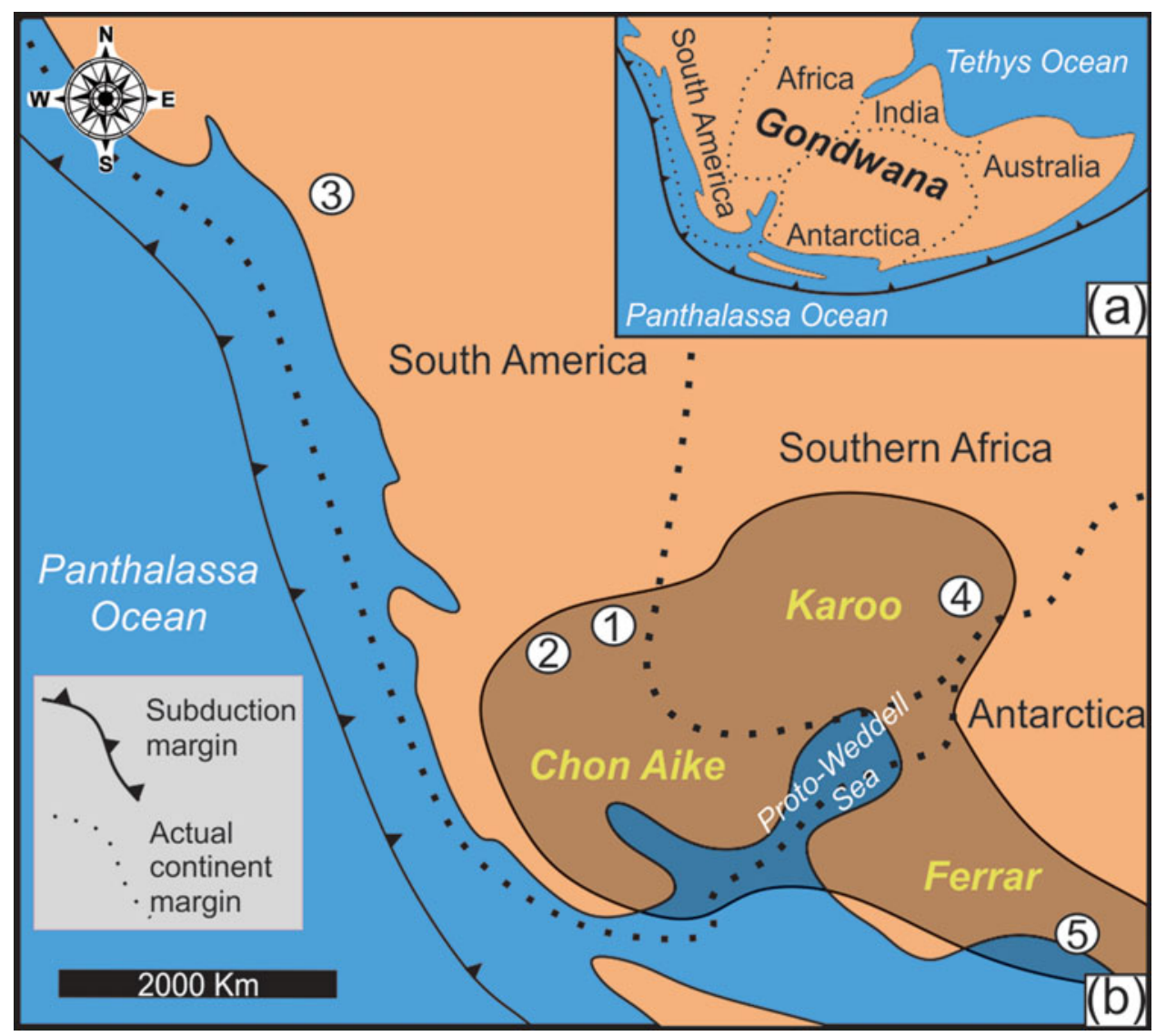

Figure 4. (Colour online) Palaeogeographic reconstruction of the SW Gondwana/Pangaea in the Late Triassic / Early Jurassic (based on Pankhurst et al. 2000; Golonka, 2007). (a) Regional view of the Gondwana landmass. (b) Detail of the reconstruction showing the Early Jurassic large igneous provinces of South Gondwana (Chon Aike, Karoo and Ferrar) and the distribution of the fossil localities mentioned in the text. 1. MVC tracksite; 2. Las Leoneras Formation; 3. Cañón del Colorado and Balde de Leyes formations; 4. Elliot Formation; and 5. Hanson Formation.

Salgado \& Gasparini, 2004; Rauhut \& López-Arbarello, 2008; de Valais, 2011; Pol, Rauhut \& Becerra, 2011) deposits.

From out of Patagonia, there are only four records for the Rhaetian-Pliensbachian time interval in South America: (1) from Argentina, two basal sauropodomophs, Adeopapposaurus mognai Martínez, 2009, and Leyesaurus marayensis Apaldetti et al. 2011, were defined from the Lower Jurassic Cañón del Colorado Formation (Martínez, 2009) and Balde de Leyes Formation (Apaldetti et al. 2011; Colombi et al. 2015), respectively; and (2) from Venezuela, the basal ornithischian Laquintasaura venezuelae and the theropod Tachiraptor admirabilis Langer et al. 2014, have been defined from the lowermost Hettangian La Quinta Formation (Barrett et al. 2008, 2014; Langer et al. 2014).

In view of the above, the dinosaur footprints studied herein are an important finding because they provide new and valuable information about the scarce dinosaur record from South America during the uppermost Late TriassicEarly Jurassic. Furthermore, these tracks are the first vertebrate ichnological remains in this continent for the RhaetianPliensbachian interval.

\section{5.c. Biochronological and palaeobiogeographical inferences}

Tetrapod footprints provide important data on the vertebrate record, both in space and in time distribution (Lucas, 2007). The footprints related to the Anomoepus-like ichnotaxa present a widespread geographical distribution and a particular temporal occurrence. Anomoepus-like footprints have been identified in the Early Jurassic from: (1) North America: USA (e.g. Olsen \& Rainforth, 2003; Lockley \& 
Gierliński, 2006; Dalman \& Weems, 2013); (2) Europe: Poland (Gierliński, 1991) and Italy (Avanzini, Gierliński \& Leonardi, 2001); (3) Asia: China (e.g. Lockley \& Matsukawa, 2009; Li et al. 2012; Xing et al. 2016b); (4) Oceania: Australia (e.g. Thulborn, 1994); and (5) Africa: Lesotho (Ellenberguer, 1970).

Other tracks related to the Anomoepus-like ichnotaxa from the Late Triassic of Poland (Niedźwiedzki, 2011) and the USA (Baird, 1964), and from the Middle Jurassic of China (Xing et al. 2015, 2016a) and Morocco (Belvedere et al. 2011) have been published. However, their ichnotaxonomical affinity or the proposed ages of the tracksites were questioned. Lockley \& Gierliński (2006) suggested that the Late Triassic tracks from the USA classified as ?Anomoepus isp. by Baird (1964) are indeed chirotheriid tracks. The Poland tracks cf. Anomoepus isp. are partly eroded and slightly deformed (Niedźwiedzki, 2011), so it is difficult to relate them with confidence to this ichnogenus. The Middle Jurassic Anomoepus-like tracks of Morocco (Belvedere et al. 2011) and the Henan province of China (Xing et al. 2016a) are similar in shape. These tracks have very slender digit impressions and narrow metatarsophalangeal pad impressions, being closer to an avian-like ichnotaxon than to Anomoepus. The Middle Jurassic tracks of Shensipus tungchuanensis Young, 1966, were first related to theropods (Young, 1966; Lockley et al. 2013). Recently, Xing et al. (2015) proposed the new combination Anomoepus tungchuanensis. Actually, the specimens are lost (sensu Xing et al. 2015), and according to the original photographs they are poorly preserved (e.g. thin layer infill tracks, very shallow anterior surface; see Young, 1966), so a confident conclusion is not possible. The Anomoepus tracks from Shaanxi province, also in China (Xing et al. 2015), originally determined as Middle Jurassic in age, have recently been included in Lower Jurassic layers based on detailed stratigraphic work (Wang et al. 2016).

The age of MVC footprints is consistent with the known temporal distribution of Anomoepus-like tracks and may represent a spatially near-global biostratigraphic occurrence (Early Jurassic biochron) of this ichnotaxon (see Haubold, 1986; Lucas, 2007). In addition, this material represents the unique Anomoepus-like tracks from South America, increasing its record almost worldwide (except in Antarctic rocks).

The palaeobiogeographic connections between the vertebrate Gondwanan palaeofaunas during the Late TriassicEarly Jurassic have been widely recognized (e.g. Yates, 2003; Langer, 2005; Pol \& Powell, 2007; Bittencourt \& Langer, 2011). Similarities have previously been noted among the basal sauropodomophs from the Norian Los Colorados Formation, Argentina (age sensu Kent et al. 2014), and the Norian Caturrita Formation, Brazil (age sensu Langer \& Ferigolo, 2013), and the palaeofauna from the Norian-Rhaetian lower Elliot Formation, southern Africa (age sensu Knoll, 2005). These similarities support the hypothesis of a palaeofaunal interchange between the southern African and South American tetrapods during the Late Triassic. The Early Jurassic fauna of South America also presents phylogenetic affinities with the upper Elliot Formation, southern Africa (Rauhut \& López-Arbarello, 2008; Martínez, 2009; Apaldetti et al. 2011; Pol, Garrido \& Cerda, 2011; Sereno, 2012), although relationships with other Gondwanan (Antarctica) and Laurasian (China) zones have also been identified (see Smith \& Pol, 2007; Rauhut \& López-Arbarello, 2008; Apaldetti et al. 2011). This happens with the Early Jurassic footprints studied herein which are close to Moyenisauripus ichnotaxon from the southern African upper Elliot Formation (sensu Ellenberger, 1970). Nevertheless, MPV 430/P/13.1 is also similar to some Early Jurassic Anomoepus-like tracks found in other places of
Gondwana (Australia; Thulborn, 1994) and Laurasia (North America, Europe and Asia; e.g. Gierliński, 1991; Avanzini, Gierliński \& Leonardi, 2001; Olsen \& Rainforth, 2003; Lockley \& Gierliński, 2006; Lockley \& Matsukawa, 2009; Li et al. 2012). This idea is consistent with the Jurassic palaeoflora from Patagonia that is comparable with the Antarctica record, but present Pangaean relationships as well (Wilf et al. 2013).

The break-up of Pangaea initiated during the Early Triassic (see Golonka, 2007, and references therein). Nevertheless, South America has remained connected to almost all the landmass of Pangaea through the Jurassic (Wilf et al. 2013). As well, Rapela et al. (2005) suggested PermianTriassic proximity between Patagonia and southern Africa according to their palaeoflora record (Archangelsky, 1990; Artabe, Morel \& Spalletti, 2003). Additionally, the uppermost Early Jurassic magmatism of Chon Aike (in which is included the MVC), Ferrar and Karoo large igneous provinces has been correlated by many authors and associated with a mantle plume precursor of the Weddell Sea opening and the separation of Gondwanan terranes (Elliot \& Fleming, 2000; Pankhurst et al. 2000; Rapela et al. 2005). This supports the idea that the current Patagonia, Africa, Antarctica and others areas of Pangaea were connected during the Early Jurassic, at least until the Weddell Sea development. Therefore, it is understandable that the Early Jurassic palaeofauna from southern South America and especially Patagonia presents a heterogeneous composition, with elements of Pangaean distribution, and others with Gondwanan relationships with prevalent southern African affinities.

Acknowledgements. We are grateful to Romina Rial, museum curator of the Museo Provincial 'María Inés Kopp', Valcheta, for providing access to the studied tracks in her care. This work was funded by project PIP $0053(\mathrm{SdV})$ from CONICET. We are especially grateful to the Perdomo family, owners of the farm, for sharing the specimens with the museum, and also, together with Gaspar Rosales, helping us with the fieldwork. Xabier Pereda-Suberbiola helped with the general logistics. We also thank Paul Upchurch for editorial assistance. Two anonymous reviewers and Paolo Citton made valuable comments that greatly improved the manuscript.

\section{References}

Apaldetti, C., Martínez, R. N., Alcober, O. A. \& PoL, D. 2011. A new basal sauropodomorph (Dinosauria: Saurischia) from Quebrada del Barro Formation (Marayes-El Carrizal Basin), northwestern Argentina. PLoS ONE, published online 9 November 2011. doi: 10.1371/journal.pone.0026964.

ArChangelsky, S. 1990. Plant distribution in Gondwana during the Late Paleozoic. In Antarctic Paleobiology: Its Role in the Reconstruction of Gondwana (eds T. N. Taylor \& E. Taylor), pp. 102-17. Berlin: SpringerVerlag.

Arcucci, A. B., Marsicano, C. A. \& Caselli, A. T. 2004. Tetrapod association and palaeoenvironment of the Los Colorados Formation (Argentina): a significant sample from Western Gondwana at the end of the Triassic. Geobios 37, 557-68.

Artabe, A. E., Morel, E. M. \& Spalletti, L. A. 2003.Caracterización de las provincias fitogeográficas triásicas del Gondwana extratropical. Ameghiniana 40, 387-405.

Avanzini, M., Gierliński, G. \& LeONARDi, G. 2001. First report of sitting Anomoepus tracks in European Lower 
Jurassic (Lavini di Marco site - northern Italy). Rivista Italiana di Paleontologia e Stratigrafia 107, 131-6.

Báez, A. M. \& Marsicano, C. A. 2001. A heterodontosaurid ornithischian dinosaur from the Upper Triassic of Patagonia. Ameghiniana 38, 271-9.

BAIRD, D. 1964. Dockum (Late Triassic) reptile footprints from New Mexico. Journal of Paleontology 38, 11825.

Barrett, P. M., Butler, R. J., Moore-Fay, S. C., Novas, F. E., Moody, J. M., Clark, J. M. \& SánchezVILlagra, M. R. 2008. Dinosaur remains from the La Quinta Formation (Lower or Middle Jurassic) of the Venezuelan Andes. Paläontologische Zeitschrift 82, 163-77.

Barrett, P. M., Butler, R. J., Mundil, R., Scheyer, T. M., IRMis, R. B. \& SÁNChEz-Villagra, M. R. 2014. A palaeoequatorial ornithischian and new constraints on early dinosaur diversification. Proceedings of the Royal Society of London B, published online 6 August 2014. doi: 10.1098/rspb.2014.1147.

Becerra, M. G., Pol, D., Rauhut, O. W. \& Cerda, I. A. 2016. New heterodontosaurid remains from the Cañadón Asfalto Formation: cursoriality and the functional importance of the pes in small heterodontosaurids. Journal of Paleontology 90, 555-77.

Belvedere, M., DyKe, G., Hadri, M. \& Ishigaki, S. 2011. The oldest evidence for birds in Northern Gondwana? Small tridactyl footprints from the Middle Jurassic of Msemrir (Morocco). Gondwana Research 19, 542-9.

Benton, M. J. 1983. Dinosaur success in the Triassic: a noncompetitive ecological model. Quarterly Review of Bio$\log y \mathbf{5 8}, 29-55$.

BitTencourt, J. S. \& LANGer, M. C. 2011. Mesozoic dinosaurs from Brazil and their biogeographic implications. Anais da Academia Brasileira de Ciências 83, 23-60.

Bonaparte, J. F. 1971. Los tetrápodos del sector superior de la Formación Los Colorados, La Rioja, Argentina. Ópera Lilloana 22, 1-183.

Bonaparte, J. F. \& Vince, M. 1979. El hallazgo del primer nido de dinosaurios triásicos (Saurischia, Prosauropoda), Triásico Superior de Patagonia, Argentina. Ameghiniana 16, 173-82.

Brusatte, S. L., Benton, M. J., Ruta, M. \& Lloyd, G. T. 2008. The first $50 \mathrm{Myr}$ of dinosaur evolution: macroevolutionary pattern and morphological disparity. Biology Letters 4, 733-6.

Brusatte, S. L., Nesbitt, S. J., Irmis, R. B., Butler, R. J., Benton, M. J. \& Norell, M. A. 2010. The origin and early radiation of dinosaurs. Earth Science Reviews 101, 68-100.

CASAmiQuela, R. M. 1964. Estudios icnológicos: problemas y métodos de la icnología con aplicación al estudio de pisadas mesozoicas (Reptilia, Mammalia) de la Patagonia. Buenos Aires: Colegio Industrial Pío IX, 229 pp.

Colombi, C. E., Santi Malnis, P., Correa, G. A., Martínez, R. N., Fernández, E., Abelín, D., Praderio, A., Apaldetti, C. G., Alcober, O. \& Drovandi, J. 2015. La formación Balde de Leyes, una nueva unidad estratigráfica de la cuenca triásica de Marayes - El Carrizal. Revista de la Asociación Geológica Argentina 72, 445-55.

Coria, R. A. \& SAlgado, L. 1995. A new giant carnivorous dinosaur from the Cretaceous of Patagonia. Nature 377, 224-6.

CortÉs, J. M. 1981. El sustrato precretácico del extremo nordeste de la provincia del Chubut. Revista de la Asociación Geológica Argentina 36, 217-35.
Cúneo, R., Ramezani, J., Scasso, R., Pol, D., Escapa, I., Zavattieri, A. M. \& Bowring, S. A. 2013. Highprecision $\mathrm{U}-\mathrm{Pb}$ geochronology and a new chronostratigraphy for the Cañadón Asfalto Basin, Chubut, central Patagonia: implications for terrestrial faunal and floral evolution in Jurassic. Gondwana Research 24, $1267-$ 75.

Dalman, S. G. \& Weems, R. E. 2013. A new look at morphological variation in the ichnogenus Anomoepus, with special reference to material from the Lower Jurassic Newark Supergroup: implications for ichnotaxonomy and ichnodiversity. Bulletin of the Peabody Museum of Natural History 54, 67-124.

De Valais, S. 2011. Revision of dinosaur ichnotaxa from the La Matilde Formation (Middle Jurassic), Santa Cruz Province, Argentina. Ameghiniana 48, 28-42.

Ellenberger, P. 1970. Les niveaux paléontologiques de première apparition des mammifères primordiaux en Afrique du Sud et leur ichnologie: établissement de zones stratigraphiques détaillées dans le Stormberg du Lesotho (Afrique du Sud) (Trias supérieur à Jurassique). In Proceedings and Papers of the Second Gondwana Symposium (ed. S. H. Haughton), pp. 343-70. Pretoria: Council for Scientific and Industrial Research.

Elliot, D. H. \& Fleming, T. H. 2000. Weddell triple junction: the principal focus of Ferrar and Karoo magmatism during initial breakup of Gondwana. Geology 28, 539-42.

Féraud, G., Alric, V., Fornari, M., Bertrand, H. \& HALLER, M. 1999. ${ }^{40} \mathrm{Ar} /{ }^{39} \mathrm{Ar}$ dating of the Jurassic volcanic province of Patagonia: migrating magmatism related to Gondwana break-up and subduction. Earth and Planetary Science Letters 172, 83-96.

GIERLIŃSKI, G. 1991. New dinosaur ichnotaxa from the Early Jurassic of the Holy Cross Mountains, Poland. Palaeogeography, Palaeoclimatology, Palaeoecology 85, 13748.

GieRLiŃSKI, G. 1999. Tracks of a large thyreophoran dinosaur from the Early Jurassic of Poland. Acta Palaeontologica Polonica 44, 231-4.

Golonka, J. 2007. Late Triassic and Early Jurassic palaeogeography of the world. Palaeogeography, Palaeoclimatology, Palaeoecology 244, 297-307.

HARRIS, J. D. 1997. Four-toed theropod footprints and a paleomagnetic age from the Whetstone Falls Member of the Harebell Formation (Upper Cretaceous: Maastrichtian), northwestern Wyoming: a correction: Cretaceous Research 18, 139.

Haubold, H. 1971. Ichnia amphibiorum et reptiliorum fossilium. Monticello, NY: Lubrecht \& Cramer, $128 \mathrm{pp}$.

Haubold, H. 1986. Archosaur footprints at the terrestrial Triassic-Jurassic transition. In The Beginning of the Age of Dinosaurs: Faunal Change across the TriassicJurassic Boundary (ed. K. Padian), pp. 189-201. Cambridge: Cambridge University Press.

Hiтchсоск, E. 1845. An attempt to name, classify, and describe the animals that made the fossil footmarks of New England. Proceedings of the Association of American Geologists and Naturalists 6, 23-5.

Hiтснсоск, E. 1848. An attempt to discriminate and describe the animals that made the fossil footmarks of the United States, and especially of New England. Memoirs of the American Academy of Arts and Sciences 3, 129 256.

Hiтснсоск, E. 1858. Ichnology of New England: A Report on the Sandstone of the Connecticut Valley especially its 
Fossil Footmarks made to the Government of the Commonwealth of Massachusetts. Boston, MA: W. White, $220 \mathrm{pp}$.

Kent, D. V., Malnis, P. S., Colombi, C. E., Alcober, O. A. \& Martínez, R. N. 2014. Age constraints on the dispersal of dinosaurs in the Late Triassic from magnetochronology of the Los Colorados Formation (Argentina). Proceedings of the National Academy of Sciences 111, 7958-63.

KNOLL, F. 2005. The tetrapod fauna of the Upper Elliot and Clarens formations in the main Karoo Basin (South Africa and Lesotho). Bulletin de la Société Géologique de France 176, 81-91.

LANGER, M. C. 2005. Studies on continental Late Triassic tetrapod biochronology. II. The Ischigualastian and a Carnian global correlation. Journal of South American Earth Sciences 19, 219-39.

Langer, M. C. \& Ferigolo, J. 2013. The Late Triassic dinosauromorph Sacisaurus agudoensis (Caturrita Formation; Rio Grande do Sul, Brazil): anatomy and affinities. In Anatomy, Phylogeny and Palaeobiology of Early Archosaurs and their Kin (eds S. J. Nesbitt, J. B. Desojo \& R. B. Irmis), pp. 353-92. Geological Society of London, Special Publication no. 379.

Langer, M. C., Rincón, A. D., Ramezani, J., Solórzano, A. \& Rauhut, O. W. 2014. New dinosaur (Theropoda, stem-Averostra) from the earliest Jurassic of the La Quinta formation, Venezuelan Andes. Royal Society Open Science, published online 8 October 2014. doi: 10.1098/rsos.140184.

LeONARDI, G. 1987. Glossary and Manual of Tetrapod Palaeoichnology. Brasilia: Departamento Nacional da Produção Mineral, Brasil, 115 pp.

Li, J. J., Lockley, M. G., Zhang, Y., Hu, S., Matsukawa, M. \& BAI, Z. 2012. An important ornithischian tracksite in the Early Jurassic of the Shenmu region, Shaanxi, China. Acta Geologica Sinica (English Edition) 86, $1-10$.

LOCKLEY, M. G. 2009. New perspectives on morphological variation in tridactyl footprints: clues to widespread convergence in developmental dynamics. Geological Quarterly 53, 415-32.

LockLEY, M. G. \& GIERLIŃSKI, G. D. 2006. Diverse vertebrate ichnofaunas containing Anomoepus and other unusual trace fossils from the Lower Jurassic of the western United States: implications for paleoecology palichnostratigraphy. New Mexico Museum of Natural History and Science, Bulletin 37, 176-91.

Lockley, M. G., dos Santos, V. F., Meyer, C. \& Hunt, A. P. 1998. A new dinosaur tracksite in the Morrison Formation, Boundary Butte, Southeastern Utah. Modern Geology 23, 317-30.

Lockley, M. G., Jianjun, L., Rihui, L., Matsukawa, M., HARRIS, J. D., \& LIDA, X. 2013. A review of the tetrapod track record in China, with special reference to type ichnospecies: implications for ichnotaxonomy and paleobiology. Acta Geologica Sinica (English Edition) 87, 1-20.

LOCKLEY, M. G. \& MatsukaWA, M. 2009. A review of vertebrate track distributions in East and Southeast Asia. Journal of the Paleontological Society of Korea 25, 1742.

Lockley, M. G, \& XING, L. 2015. Flattened fossil footprints: implications for paleobiology. Palaeogeography, Palaeoclimatology, Palaeoecology 426, $85-94$.

LuCAS, S. G. 2007. Tetrapod footprint biostratigraphy and biochronology. Ichnos 14, 5-38.
LULL, R. S. 1904. Fossil footprints of the Jura-Trias of north America. Memoirs of the Boston Society of Natural History 5, 461-557.

Mallison, H. \& Wings, O. 2014. Photogrammetry in paleontology: a practical guide. Journal of Paleontological Techniques 12, 1-31.

Martínez, R. N. 2009. Adeopapposaurus mognai, gen. et sp. nov. (Dinosauria: Sauropodomorpha), with comments on adaptations of basal Sauropodomorpha. Journal of Vertebrate Paleontology 29, 142-64.

NiedźwIEDZKI, G. 2011. A Late Triassic dinosaurdominated ichnofauna from the Tomanová Formation of the Tatra Mountains, Central Europe. Acta Palaeontologica Polonica 56, 291-300.

Novas, F. E. 2009. The Age of Dinosaurs in South America. Bloomington, IN: Indiana University Press, $452 \mathrm{pp}$.

Olsen, P. E. \& Galton, P. M. 1984. A review of the reptile and amphibian assemblages from the Stormberg of southern Africa, with special emphasis on the footprints and the age of the Stormberg. Palaeontologia Africana 25, 87-110.

Olsen, P. E. \& Rainforth, E. C. 2003. The Early Jurassic Ornithischian Dinosaurian Ichnogenus Anomoepus. In The Great Rift Valleys of Pangea in Eastern North America (eds P. M. LeTourneau \& P. E. Olsen), pp. 314 67. New York: Columbia University Press.

Pankhurst, R. J., Leat, P. T., Sruoga, P., Rapela, C. W., MÁrquez, M., Storey, B. C. \& Riley, T. R. 1998. The Chon Aike province of Patagonia and related rocks in West Antarctica: a silicic large igneous province. Journal of Volcanology and Geothermal Research 81, 113-36.

PANKhurst, R. J. \& RAPEla, C. R. 1995. Production of Jurassic rhyolite by anatexis of the lower crust of Patagonia. Earth and Planetary Science Letters 134, 23-36.

Pankhurst, R. J., Riley, T. R., Fanning, C. M. \& Kelley, S. P. 2000. Episodic silicic volcanism in Patagonia and the Antarctic Peninsula: chronology of magmatism associated with the break-up of Gondwana. Journal of Petrology 41, 605-25.

Pol, D., Garrido, A. \& Cerda, I. A. 2011. A new sauropodomorph dinosaur from the Early Jurassic of Patagonia and the origin and evolution of the sauropod-type sacrum. PloS ONE, published online 26 January 2011. doi: 10.1371 /journal.pone.0014572.

PoL, D. \& Powell, J. E. 2007. Skull anatomy of Mussaurus patagonicus (Dinosauria: Sauropodomorpha) from the Late Triassic of Patagonia. Historical Biology 19, 12544.

Pol, D. \& Rauhut, O. W. M. 2012. A Middle Jurassic abelisaurid from Patagonia and the early diversification of theropod dinosaurs. Proceedings of the Royal Society B, published online 23 May 2012. doi: 10.1098/rspb.2012.0660.

Pol, D., Rauhut, O. W. \& Becerra, M. 2011. A Middle Jurassic heterodontosaurid dinosaur from Patagonia and the evolution of heterodontosaurids. Naturwissenschaften 98, 369-79.

Rapela, C. W., Pankhurst, R. J., Fanning, C. M. \& Herve, F. 2005. Pacific subduction coeval with the Karoo mantle plume: the Early Jurasssic Subcordilleran belt of northwestern Patagonia. In Terrane Processes at the Margins of Gondwana (eds A. P. M. Vaughan, P. T. Leat \& R. J. Pankhurst), pp. 217-39. Geological Society of London, Special Publication no. 246.

Rauhut, O. W. \& López-Arbarello, A. 2008. Archosaur evolution during the Jurassic: a southern perspective. 
Revista de la Asociación Geológica Argentina 63, 55785.

Rauhut, O. W., Remes, K., Fechner, R., Cladera, G. \& Puerta, P. 2005. Discovery of a short-necked sauropod dinosaur from the Late Jurassic period of Patagonia. Nature 435, 670-72.

Salgado, L. \& Bonaparte, J. F. 1991. Un nuevo saurópodo Dicraeosauridae, Amargasurus cazaui gen. et sp. nov., de la Formación La Amarga, Neocomiano de la provincia del Neuquén, Argentina. Ameghiniana 28, 333-46.

SAlgado, L. \& GASPARINI, Z. 2004. El registro más antiguo de Dinosauria en la Cuenca Neuquina (Aaleniano, Jurásico Medio). Ameghiniana 41, 505-8.

SERENO, P. C. 2012. Taxonomy, morphology, masticatory function and phylogeny of heterodontosaurid dinosaurs. Zookeys 226, 1-225.

Smith, N. D. \& Pol, D. 2007. Anatomy of a basal sauropodomorph dinosaur from the Early Jurassic Hanson Formation of Antarctica. Acta Palaeontologica Polonica 52, 657-74.

SternberG, C. M. 1926. Dinosaur tracks from the Edmonton Formation of Alberta. Geological Survey of Canada Bulletin 44, 85-7.

Thulborn, T. 1990. Dinosaur Tracks. London: Chapman and Hall, $410 \mathrm{pp}$.

Thulborn, T. 1994. Ornithopod dinosaur tracks from the Lower Jurassic of Queensland. Alcheringa 18, 247-58.

Wang, B., Li, J., BaI, Z., GaO, J., Dong, S., Hu, B., ZhaO, Q. \& ChANG, J. 2016. Research on dinosaur footprints in Zizhou, Shaanxi Province, China. Acta Geologica Sinica (English Edition) 90, 1-18.
Wilf, P., CÚNeO, N. R., Escapa， I. H., Pol, D. \& Woodburne, M. O. 2013. Splendid and seldom isolated: the paleobiogeography of Patagonia. Annual Review of Earth and Planetary Sciences 41, 561-603.

Wright, J. L. 2004. Bird-like features of dinosaur footprints. In Feathered Dragons (eds P. J. Currie, E. B. Koppelhus, M. A. Shugar \& J. L. Wright), pp. 16781. Bloomington, IN: Indiana University Press.

Xing, L., Abbassi, N., Lockley, M. G., Klein, H., JiA, S., McCrea, R. T. \& Persons IV, W. S. 2016a. The first record of Anomoepus tracks from the Middle Jurassic of Henan Province, Central China. Historical Biology, published online 22 February 2016. doi: 10.1080/08912963.2016.1149480.

Xing, L., Lockley, M. G., TANG, Y., Klein, H., Zhang, J., Persons IV, W. S. \& Ye, Y. 2015. Theropod and Ornithischian footprints from the Middle Jurassic Yanan Formation of Zizhou County, Shaanxi, China. Ichnos 22, 1-11.

Xing, L., Lockley, M. G., Zhang, J., You, H., Klein, H., Persons IV, W. S., Dai, H. \& Dong, Z. 2016 b. First Early Jurassic Ornithischian and theropod footprint assemblage and a new ichnotaxon Shenmuichnus wangi ichnosp. nov. from Yunnan Province, southwestern China. Historical Biology 28, 721-33.

YATES, A. M. 2003. A definite prosauropod dinosaur from the lower Elliot Formation (Norian: Upper Triassic) of South Africa. Palaeontologia Africana 39, 63-8.

Young, C. C. 1966. Two footprints from the Jiaoping Coal Mine of Tungchuan, Shensi. Vertebrata PalAsiatica 10, 68-71. 